ment which is specially advantageous for ultra-violet and infra-red microspectrography. Other specialized techniques under development include various forms of phase-contrast and interference microscopy, which are now being used for a general programme concerned with the action of physical and chemical agents on living cells. Recently, new methods have been devised for the optical determination of cell mass and the regional concentration of solids within living cells. Some applications of these are likely to prove of considerable value in clinical pathology.

A grant of $£ 1,500$ a year for three years has also been maide by the National Coal Board for research work to be carried out in the Department of Human Anatomy (under the direction of Dr. J. S. Weiner) in collaboration with the Medical and Rescue Personnel Departments of the Board. For some years the Medical Research Council Climatic and Working Efficiency Unit in the Department has been engaged on fundamental and applied investigations on human adaptation to climate, particularly to hot environments. It is now proposed that this work should be extended to include mining problems concerning the effect of hot and humid atmospheres on health and efficiency. This work was pioneered many years ago by the late Prof. J. S. Haldane and Prof. Neville Moss, and its development in the Department of Human Anatomy at Oxford, at Singapore and (during the Second World War) at the National Hospital, Queen Square, London, has yielded a knowledge of methods and an accumulation of data much of which is particularly applicable to mining problems. The Unit at Oxford has already played a part in the inauguration of similar work in the South African gold mines. The immediate inquiries on behalf of the National Coal Board will be concerned with the performance of rescue personnel at high temperatures and with the effect of age on the ability to withstand high temperatures.

\section{Functions of the Ductless Glands: Fiftieth Anniversary}

For the scientific investigator, the most difficult of all feats is to form a new idea in the face of prevailing dogma. At the end of the nineteenth century the body was regarded as a collection of organs co-ordinated and integrated by the nervous system, and the function of individual organs was explained in terms of their nervous connexions. But it was well known that a nerveless pancreas did secrete when acid food entered the intestine. Physiologists, baffled, searched for new nervous paths. Fifty years ago, in 1902, Starling, working in University College, London, suddenly had a new idea that it must be a chemical reflex, and quickly proved this by grinding up the lining of the intestine with some weak acid, injecting it into the blood and obtaining an immediate flow of pancreatic juice. This intestinal substance was called secretin because it caused the pancreas to secrete. The functions of most endocrine glands were known; but it was not until the discovery of secretin that their role in the overall organization of the body was understood. From the example of secretin, Starling and his fellow-worker, Bayliss, postulated that the higher animals possess, in addition to the nervous system, a second co-ordinating and integrating system: substances formed in one organ circulate in the blood and regulate the function of another organ or site. To these they gave the name 'hormone' (to excite), and said that, when this word was used, the attribute of messenger should be understood. This idea of a blood-borne regulation of normal body functions has proved to be one of the most fruitful in physiology, and to-day, with the advent of cortisone and adrenocorticotropic hormone, may be ready to give us a new concept of disease.

\section{Colonial Research and Development}

THE debate on the Queen's Speech in the House of Commons on November 7 was concerned with Colonial affairs; but attention was focused on the situation in Kenya, and, except in Mr. Bernard Braine's speech, Colonial research received no attention. Mr. Braine, in directing attention to the importance of Colonial development, stressed particularly the urgent need for improved transport and more knowledge about the Colonies and their human and physical resources. In this connexion he referred to some achievements in Colonial research and in particular to the work of the Colonial Products Research Council. Sir Leslie Plummer supported Mr. Braine's remarks on the importance of research, particularly agricultural research. Mr. Braine pleaded for early clarification of the present uncertainty arising from the expiry in March 1956 of the Acts under which the Colonial Development and Welfare Schemes are financed. The Colonial Research Council has already pointed out in its current report. that uncertainty is making the planning of long-term research impossible and hindering the recruiting of research workers for the Colonial territories. Nevertheless, no comment on this matter was made when the Under-Secretary of State for Commonwealth Relations replied on the debate.

\section{Laterite and Lateritic Soils}

IN Technical Communication No. 47 of the Commonwealth Bureau of Soil Science, entitled "Laterite and Lateritic Soils" (pp. 51; from the Bureau, Farnham Royal ; 1952 ; 6s.), J. A. Prescott and R. L. Pendleton, the distinguished authors of this publication, quote the early, lucid and authoritative descriptions given by F. Buchanan (1807) and T. J. Newbold (1844). They illustrate the strikingly cellular nature of laterite by photographs of the material when used in building, and present maps showing its wide distribution in India, Australia and Africa. Laterite occurs at shallow depth and at the surface, and the bare slag-like sheets are believed to be the exposed illuvial horizon of an ancient soil. This material has a high content of sesquioxides and is usually associated with resistant minerals and with kaolinite, which may perhaps be formed by silification of gibbsite. In discussing the mobility of sesquioxides, Prescott and Pendleton suggest that high acidity resulting from oxidation of ferrous sulphides may have a bearing on the origin of laterite. Examination of Australian laterite suggests that gallium, molybdenum, lead, vanadium and zinc are concentrated with the iron, and deficiencies of copper, manganese and phosphorus have been noted where present-day soils have developed from broken-down laterite formations; such soils are usually infertile. The red earths and red loams of the tropics are formed from a variety of rocks as well as from broken-down lateritic formations, and it is unfortunate that they have received names such as 'laterite', 'lateritic soil' or 'latosol'. Prescott and Pendleton agree with the United States Soil Survey staff that it would be better to confine the word 'laterite' to such ferruginous materials as harden on exposure and to the relicts of such materials. These relicts can be found in several 